\title{
Recommendations for full-spectrum sustainability in Canadian lobster integrated management plans based on a socioeconomic analysis of Barrington, Nova Scotia
}

\author{
Allain J. Barnett ${ }^{1,2}$
}

\begin{abstract}
Fisheries and Oceans Canada has developed integrated fisheries management plans to promote a more holistic approach to fisheries management. Yet these management plans maintain an emphasis on the ecological domains, without sufficient attention to socioeconomic and institutional domains of management. In this study, I use a case study from Barrington, Nova Scotia, and dimensions from the Canadian Fisheries Research Network Comprehensive Sustainability Framework to demonstrate the importance of socioeconomic and institutional indicators to contribute to fisheries management plans. An analysis of survey data of captains and lobster fishing households revealed decreased access to multiple species fishing strategies, partially because of large inequities in access to individual fishing quotas. Harvesters with a high dependence on lobster as the primary source of income had lower incomes, and higher income sensitivity to the financial crisis of 2008. New strategies have emerged to cope with reduced access to multiple species, and high-yield lobster fishing is often the best available strategy to pay bills and meet costs when lobster prices are low. Outcomes for the region were split, with an equal number of harvesters reporting recent years as the best or worst year they experienced in fishing. Given a history of changing regulations and reduced options to remain flexible when economic and ecological conditions change, harvesters were pessimistic about their future access, and their children's future access, to fisheries. Harvesters faced livelihood challenges caused by cumulative effects of multiple regulatory and ecological events. I demonstrate how the Canadian Fisheries Research Network Comprehensive Sustainability Framework can guide researchers, managers, and fishing organizations to understand the current management objectives that are not being met, and to develop research priorities, methods, protocols, and personnel to meet a broader spectrum of objectives.
\end{abstract}

Key Words: Canada; equity; groundfish; livelihoods; lobster; Nova Scotia; property rights; quota; stewardship

\section{INTRODUCTION}

The Canadian Integrated Fisheries Management Plans (IFMPs) were developed in the mid-1990s to improve management, consider ecological, socioeconomic, and institutional domains, and enhance input from resource users and other stakeholders. Although such management approaches have facilitated innovations in the management process, conventional fisheries management has continued to neglect the diversity of social, economic, and institutional objectives that would facilitate a holistic form of sustainability, including sustainable households, livelihoods, coastal communities, and economies (Wiber 2000, Degnbol et al. 2006, Pinkerton 2009, Stephenson et al. 2017). How can we overcome the inertia of the current governance pathway (Stephenson et al. 2017) to facilitate the integration of a diversity of disciplines and knowledges to fisheries management?

I apply the Canadian Fisheries Research Network (CFRN) Comprehensive Fisheries Sustainability Framework (hereafter referred to as the CFRN Sustainability Framework), which emphasizes the importance of considering all four necessary elements to build sustainability: the social, economic, ecological, and institutional. I apply survey data and analysis from a study in southwest Nova Scotia (SWNS) to contribute to the Canadian Fisheries Research Network's (CFRN) objective of promoting more holistic and comprehensive measures of sustainability. I will use a case study from Barrington, Nova Scotia, and dimensions of the CFRN Sustainability Framework to contribute to Canada's lobster (Homarus americanus) IFMP and fisheries IFMPs in general. This will provide further policy guidance, specifically for efforts to improve the quality of socioeconomic data and analysis of the distribution of benefits, livelihoods, and fishing strategies, and to contribute to the institutional domain of fisheries management.

\section{Literature review}

Fisheries research suggests that diversity can build resilience. Harvesters can build resilience to changing economic and ecological conditions through access to a diversity of resources, employment opportunities, and resource-use strategies. Breen et al. (2016) recommend a portfolio approach to fisheries management to better understand how harvesters with access to multiple species will respond to regulations or quotas for single species. Portfolio theory has been applied to agricultural systems, but has also been suggested as an approach to balance ecological conservation with individual harvester goals (Hanna 1998), or as a means of building the resilience of fishing communities to fluctuations in price and species abundance (Hilborn et al. 2001, Stoll et al. 2016). Vulnerability and resilience research has taken a broader perspective by examining the link between social resilience and resource dependency (Marshall et al. 2007, Marshall 2011). Marshall et al. (2007) examined resource dependency using indicators of attachment to place, occupation, and employability, and demonstrated that harvesters with social and economic dependency on resources were more vulnerable to institutional change. These studies all point to the importance of flexibility through access to multiple social, economic, institutional, and natural resources.

Distributional equity remains a challenge to building comprehensive sustainability and resilience measures for fisheries 
Table 1. Summary of ecological, socioeconomic, and institutional goals and strategies of the Maritimes lobster Integrated Fisheries Management Plan (IFMP).

\begin{tabular}{|c|c|c|}
\hline $\begin{array}{l}\text { Domain } \\
\text { Dimension }\end{array}$ & Goal & Maritimes Lobster IFMP goals and strategies \\
\hline \multicolumn{3}{|l|}{ Ecological } \\
\hline \multirow[t]{2}{*}{ Conservation } & $\begin{array}{l}\text { Ecological productivity and } \\
\text { geographic range }\end{array}$ & $\begin{array}{l}\text { Moderate fishing mortality, limit bycatch, allow escapement, and protect reproductive } \\
\text { seasons }\end{array}$ \\
\hline & Biodiversity & $\begin{array}{l}\text { Protect incidental mortality of North Atlantic right whales (Eubalaena glacialis) and } \\
\text { other species }\end{array}$ \\
\hline \multirow{2}{*}{$\begin{array}{l}\text { Habitat and ecosystem } \\
\text { integrity }\end{array}$} & Substrate quality & Manage disturbance to bottom and limit debris \\
\hline & Water quality & Limit introduction of pollutants \\
\hline \multicolumn{3}{|l|}{ Socioeconomic } \\
\hline Equity and fairness & Access stability & Promote stability of access to resources and allocations through licensing \\
\hline \multirow[t]{3}{*}{ Economic and financial } & Financial viability & Promote economically prosperous fisheries \\
\hline & & $\begin{array}{l}\text { Provide internal mechanisms that allow self-adjustment of capacity to resource } \\
\text { availability through partnerships and stacking }\end{array}$ \\
\hline & Markets & Support certification for sustainability \\
\hline \multicolumn{3}{|l|}{ Institutional } \\
\hline \multirow[t]{3}{*}{ Structure } & Rules & Trap limits, legal size limits, seasons, escapement hatches \\
\hline & & $\begin{array}{l}\text { Limited-entry licensing with partnerships and stacking options (two licenses on one } \\
\text { boat) }\end{array}$ \\
\hline & Agreements & Consultation process \\
\hline \multirow[t]{2}{*}{ Process } & Collaborative & $\begin{array}{l}\text { Advisory committee process as a consultation forum for shared stewardship } \\
\text { arrangements and issue specific consultation }\end{array}$ \\
\hline & Flexibility & Promote flexibility in policy and licensing \\
\hline Outcomes & Compliance & Strong enforcement \\
\hline
\end{tabular}

and other resource systems (Loomis and Ditton 1993, Daigle et al. 1996, Adger 2003, Barnett and Eakin 2015). Many scholars have expressed concerns regarding the distributional consequences of quota management systems, especially individual transferable quotas (ITQs; Wiber 2000, Mansfield 2004, Pinkerton and Edwards 2009, Carothers and Chambers 2012, Macinko 2014). Narrow property rights approaches that do not pay sufficient attention to the social embeddedness of fishing practices (McCay and Jentoft 1998, Foley et al. 2015) can drastically change the distribution of access to resources in fishing communities, causing significant social and economic challenges. Because allocating property- or quasi-property rights generates a large stream of benefits to harvesters or owners, it is important to consider how these benefits are distributed among fishing communities, and how modifications to property rights and associated regulations will change this distribution (McCay et al. 1995, Bromley 2008, 2009, Pinkerton and Edwards 2009, Macinko 2014).

Building resilience and avoiding adverse distributional impacts in fisheries requires better information flows and feedback between managers and harvesters (Brewer 2012, Barnett and Anderies 2014). These information flows may be improved through adaptive comanagement, whereby harvesters, managers, and other relevant stakeholders share decision-making power to govern natural resource systems. Scholars suggest that adaptive comanagement can facilitate effective responses to economic and ecological change through social learning, experimentation, and information sharing (Cash et al. 2006, Armitage et al. 2009, Eriksen and Lind 2009, Wise et al. 2014, Chaffin and Gunderson 2016). The effectiveness of these approaches, however, will depend on how well a comanagement initiative integrates with existing organizations, networks, and socioeconomic and ecological conditions (Ruitenbeek and Cartier 2001, Plummer 2009, Parlee and Wiber 2014, Sayles and Baggio 2017).

The challenge of developing an adaptive approach to fisheries management with power sharing among stakeholders and government, and with attention to distributional equity, implies a greater role for social science in fisheries management. Social science scholars can build on and supplement ecological and biological research by examining the implications of ecological, economic, and regulatory change for fishing communities. In this study, I focus on the socioeconomic and institutional domains of the CFRN Sustainability Framework by examining the dynamics of the fisheries of Barrington. I will examine the current distribution of access to quota fisheries as an additional source of income to lobster fishing, the implications of this distribution of access for livelihoods, practices, and harvesters' reported outlook for the future.

The CFRN brought together academic researchers, the fishing industry, and government researchers and managers from across Canada to overcome information gaps, enhance ecological sustainability, improve operational efficiency, and improve the basis for an ecosystem approach to fisheries management. The CFRN Sustainability Framework emerged from a research project focused on developing enhanced fisheries knowledge for an evolving management regime (CFRN 2012). The CFRN Sustainability Framework can serve as a tool that enables fisheries research and management approaches to pay attention to a broader set of socioeconomic, ecological, and institutional aspects (Stephenson et al. 2017). I will use insights from this analysis and the CFRN Sustainability Framework to develop recommendations for lobster IFMPs. Table 1 summarizes the 
lobster IFMP with written goals and strategies categorized according to the domains, dimensions and goals of the CFRN Sustainability Framework. The lobster IFMP implies a balance in managing lobster fisheries to meet ecological, socioeconomic, and institutional goals. Fisheries and Oceans Canada (DFO) recommends a precautionary approach to achieve conservation and socioeconomic goals, and suggested that the plan can be improved with better data quality, protection for mature female lobsters, and governance. This study will contribute to improved data and analysis, and recommendations for a broader set of socioeconomic and institutional indicators.

\section{METHODS}

\section{Study area}

Barrington municipality consists of various fishing wharves and communities in Shelburne County, Nova Scotia (Fig. 1). Davis' (1980) study of Port Lameron (a pseudonym for Port La Tour) described a fishery with many similarities to Acheson's (1988) lobster gangs of Maine. Harvesters fished year-round with access to various species, including cod (Gadus morhua), halibut (Hippoglossus hippoglossus), herring (Clupea harengus), mackerel (Scomber scombrus), and lobster, and using various fishing technologies, including gill nets, hand-lines, jigs, longlines, and lobster traps (Davis 1980). Harvesters collectively protected their fishing grounds and spatially organized technology-use through an informal management system. Over the past 30 years, the fisheries have undergone a transformation because of regulatory and ecological change. Smaller-scale activities such as hand-lining have nearly disappeared, and most finfish vessels now use longlines. Although fisheries still exist for traditional species, their role for fishing livelihoods are diminished.

Fig. 1. Map of study area, including names of active fishing wharves.

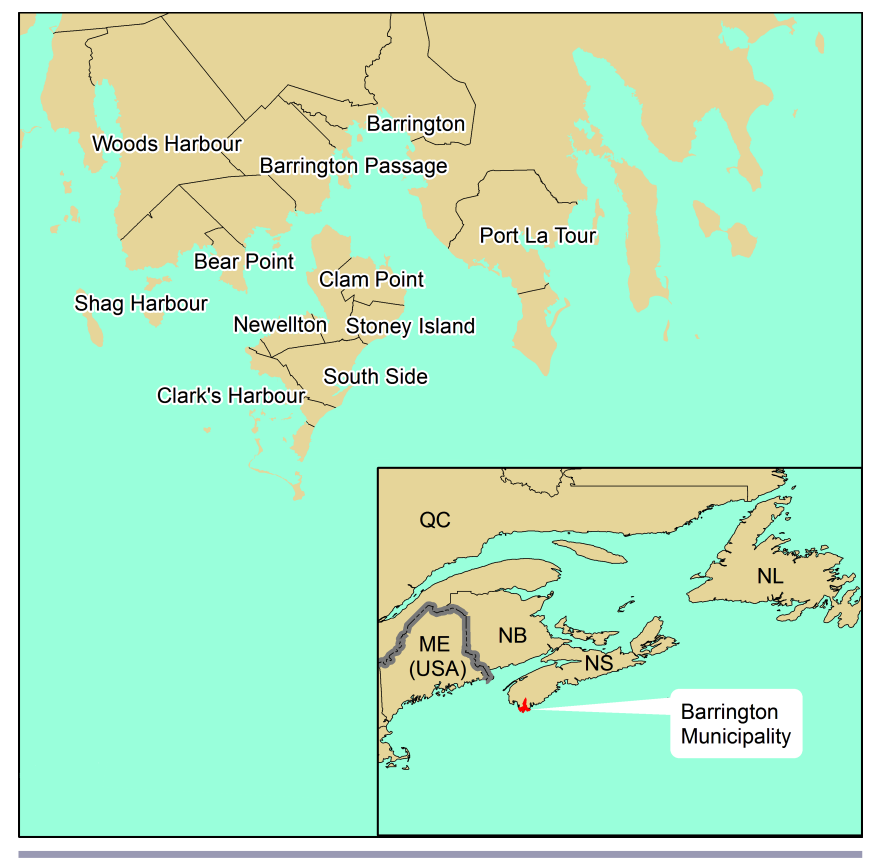

Most harvesters in the region and all captains in this study fished for lobster. The lobster fishery is managed through transferable limited-entry licenses, with trap limits, fishing seasons, lobster fishing districts, a minimum size restriction, and a restriction on landing egg-bearing female lobsters. The lobster fishery is the last lucrative fishery in Atlantic Canada without a quota management system. Lobster fishing associations have lobbied government to limit vertical integration and privatization, and to maintain the independence of small-scale owner-operator fleets (see Barnett et al. 2017)

Most fishing ports in Barrington have licenses for Lobster Fishing Area (LFA) 34, though Port La Tour harvesters mostly fish in LFA 33 to the northeast. LFA 34 has the highest landings and most participants of all LFAs in Canada. Three-year average catch and catch per unit effort in LFA 34 reached record highs in 2015, with a total catch of 24,111 metric tonnes (DFO 2016a), five times higher than 1980 landings. LFA 33 has experienced similar increases in catches and catch per unit effort, with 2016 catches at a record high of 10,049 metric tonnes (DFO 2016b). Stock status reports for both LFAs suggest that fishing effort and stocks are in a "healthy zone." The health of lobster stocks, however, contrasts with the decline of groundfish species (Frank et al. 2013, Sinclair et al. 2015), with the exception of Atlantic halibut stocks, which have begun to recover from a history of overfishing (Trzcinski and Bowen 2016, DFO 2017). These declines coincided with the DFO's roll-out of individual transferable quota (ITQ) systems, replacing competitive total allowable catch (TAC) systems, throughout the 1980s and 1990s.

\section{Surveys}

I conducted surveys in Barrington municipality in 2012 using field-tested questionnaires implemented both in Nova Scotia (Fishermen and Scientist Research Society, http://www.fsrs.ns.ca/ inshore-research.html) and elsewhere (see Grootaert and Van Bastelar 2002, Harlan 2003, Eakin and Bojórquez-Tapia 2008) to develop a questionnaire with external validity and local relevance. Survey questions elicited responses regarding a fishing householes (1) participation in fisheries and quota ownership; (2) sensitivity to prices and environmental change; (3) participation in associations or organizations; (4) attachment to fishing and thoughts of the future of the fishery; (5) assessment of cooperation in the community; (6) assets and debts; (7) education, household employment, and income (for protocol see Barnett 2014). All captains surveyed were male. Most captains were owner-operators, except for 10 who were fishing lobster under a controlling agreement. I pretested questionnaires with five captains. During pretests, I recorded each captain's response to the questions, clarifying questions, and their thoughts on the appropriateness of questions. Pretest responses were used to edit the survey protocol. Because names on the official lists of 338 license-holders in the area are confidential, I used snowball sampling to develop a list of respondents, and contacted recruited respondents randomly from this list. I also recruited some survey respondents during participant observation on fishing vessels, at the wharf, and at shore-based facilities. I conducted the finalized survey in face-to-face interviews with 94 captains. The response rate for surveys was $85.6 \%$ of people contacted either in person or by phone. 


\section{Analysis}

Multispecies fishing access

I examined the degree to which lobster harvesters participated in secondary fisheries, the percentage of captains that participated in these fisheries, and the distribution of access to the three most important secondary fisheries in the region; groundfish, halibut, and swordfish (Xiphias gladius). Access is determined primarily by the amount of quota a captain owns. Thus, I measured the inequality of quota ownership among captains using the gini index. The gini index is based on the Lorenz curve, which itself is obtained by plotting the proportion of total income of a population cumulatively earned by $\mathrm{x} \%$ of the population. The gini index is calculated as the area between the Lorenz Curve and a line of equality, where the relationship between proportion of total income and cumulative earnings is one to one. I calculated gini index values for groundfish, halibut, and swordfish quota ownership using R. Although some degree of inequality should be expected in quota ownership, here I use the gini index to illustrate the degree of inequality of access, and to consider the consequences of this inequality for fishing practices and livelihoods. The change from TACs to ITQs makes it difficult to provide a baseline of access for comparison to current levels of inequality. Historical accounts of the fishery, however, demonstrate that harvesters used a flexible strategy relying on their access to multiple species to obtain stable, albeit often lower, incomes (Davis 1980, 1984, 1991, Barnett 2014).

\section{Factors influencing income, income sensitivity, and crew} remuneration

Survey responses were used to estimate characteristics of the captains, households, and fishing practices (age, total catch), their financial conditions (boat payments, controlling agreements, whether they entered the fishery with financial credit after 1999), access to fish species (groundfish, halibut, and swordfish quota), dependency (the percentage of household income derived from lobster fishing), and vessel characteristics (boat length and width). Harvesters suggested that these variables would be important to determining income and sensitivity during interviews and informal discussions. Whether a harvester entered the fishery with credit after 1999 was used as an estimate of costs of entry and debts, because harvesters, experts, and previous studies have indicated that the costs of entry rose significantly by the year 2000 (Coates 2000, Bodiguel 2002). Harvesters have lobbied government to eliminate controlling agreements, contractual agreements in which a financier effectively leases a license out to a captain. Controlling agreements are said to weaken the independence of the owner-operator fleets, and reduce a captain's and crew's share of revenues from fishing (Barnett and Eakin 2015, Barnett et al. 2017).

I examined the importance of the above factors in explaining household income, income sensitivity, and winter crew shares, using logistic and linear regressions (STATA). I used an ordinal scale to measure household income (i.e., 0-20,000, 20,001$40,000 \ldots)$, and thus ordinal logistic regression to predict income. The outcome variable for income sensitivity asked whether a captain's income had increased, stayed the same, or decreased since 2006, a peak year after which lobster prices began to decline and fishing costs began to increase. Only 18 out of the 94 surveyed captains reported an increase in income since 2006, and ordered logistic regressions did not meet the parallel odds assumption. This variable was thus transformed into a binary variable indicating whether a captain reported a decrease in their income or not. Finally, I used a linear regression model, using a robust standard error estimation (due to heteroskedasticity of variance) to explain winter crew shares. The winter crew shares are the most important because most of the income for captains and their crew is made in the first month of lobster fishing. This dependent variable is a rough estimation of crew remuneration; overall income, of course, will depend on days worked and catches throughout the season. All regression results are reported with both the full model (all variables entered) and reduced model (only significant or weakly significant variables included).

\section{Subjective well-being among harvesters and quota owners}

To assess subjective well-being among harvesters and quota owners, I used survey data on respondents' optimism for their future access to lobster and quota fisheries, and their outlook for their children's future in fisheries. I examined, via a t-test, whether harvesters' optimism for their future access to quota fisheries was greater if they owned more quota. This tested the prediction that quotas, often described as private property rights, though more accurately described as transferable privileges (Bromley 2009), would provide harvesters a sense of security of tenure. I compared responses to a survey question asking whether the respondent would go into fishing if they had their life to live over again, to questions asking whether they would advise their children to go into fishing if they entered (1) from scratch (no inherited or acquired licenses or quotas), (2) with a lobster license, or (3) with a lobster license and quotas (Wilcoxon signed-rank test).

Finally, I examined harvesters' sense of well-being over time, and the degree to which these perceptions were shared among harvesters, by examining harvester reports of their best and worst years in fishing. I used these reports, combined with qualitative responses of why these years were best or worst, and with reference to historical events in Barrington and SWNS.

\section{RESULTS}

\section{Access to multiple species}

Overall, a total of $51 \%$ of captains fished only for lobster. Secondary fisheries included groundfish (haddock Melanogrammus aeglefinus, cod, Atlantic hake Urophycis tenuis; $29 \%$ of captains), halibut ( $18 \%$ of captains), swordfish ( $16 \%$ of captains), Irish moss Chondrus crispus (9\% of captains) and bluefin tuna Thunnus thynnus (3\% of captains). The rarest fisheries in the sample included "slime-eel" (Atlantic hagfish Myxine glutinosa), Atlantic sea scallops Placopecten magellanicus, and snow crab Chionoecetes opilio, with only $1 \%$ of captains participating. Davis (1984) estimated that $40 \%$ of a Port La Tour harvester's income came from lobster fishing, with most of their remaining income derived from groundfish. In 2012, responses to this survey indicate that $82 \%$ of harvester incomes came from lobster fishing. On average, captains who fished for 1 or more additional species to lobster were 48 years old, while captains who fished only for lobster were 57 years old (t-test assuming unequal variance, $\mathrm{P}<$ $0.01)$.

Figure 2 shows that quota ownership among captains was highly skewed with most captains owning between 0 and 5000 pounds of quota for groundfish, swordfish, or halibut. The gini index for 
groundfish, swordfish, and halibut quota was $0.83,0.95$, and 0.92 respectively, indicating large inequalities in quota ownership. To illustrate this inequality, the top $13.3 \%$ (12 captains) owned $80.4 \%$ of the groundfish quota, while the bottom $50 \%$ (45 captains) owned $1.6 \%$. The mean groundfish quota ownership among active groundfishing captains was 43,000 pounds, while inactive quota owners who no longer fished for groundfish held 5800 pounds (ANOVA, $P=0.001$ ). This result corroborates reports from captains and experts that a vessel would need to acquire enough quota to make at least three or four trips per year to make an income and pay for the costs of maintaining fishing gear. Captains with 43,000 pounds of quota would likely have enough for three or four trips, however, many captains stated that they often leased additional quota either to make up for quota over-runs, or to make additional fishing trips. Together, these results suggest that a much smaller percentage of harvesters today have access to multiple species, and that there are large inequities among harvesters in access to quota fish species.

Fig. 2. Histogram of quota ownership for groundfish, swordfish (Xiphias gladius), and halibut (Hippoglossus hippoglossus) among fishing captains in Barrington Municipality.

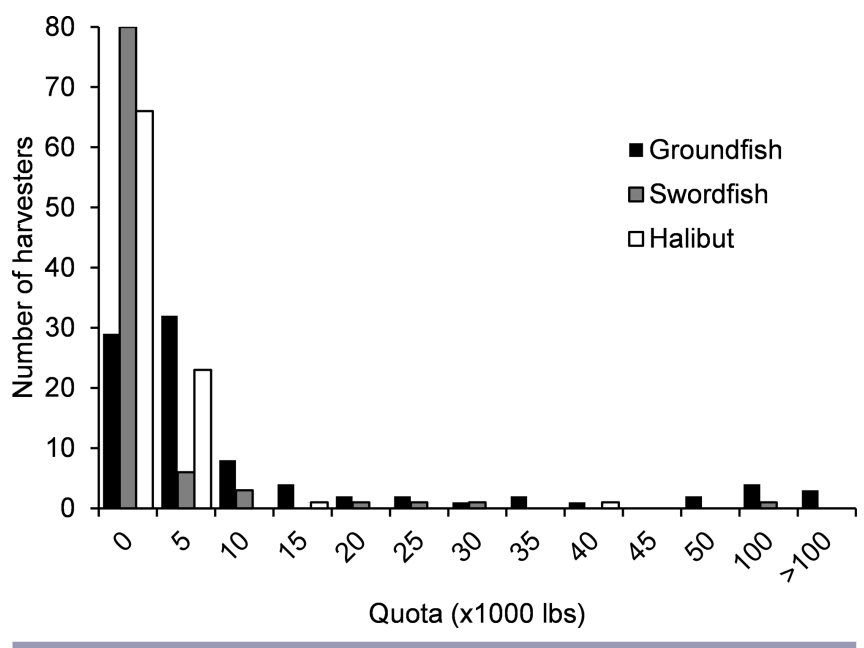

Factors influencing income, income sensitivity, and crew remuneration

Regression results below demonstrate the relationship between independent variables (controlling for all other independent variables) and income, income sensitivity, and crew remuneration. Table 2 indicates that captains who were younger, had higher catches, were less dependent on lobster, or had relatively longer boats had higher incomes $\left(P<0.0001\right.$, Pseudo $\left.R^{2}=0.2303\right)$.

The resulting logistic regression for income sensitivity (Table 3) again indicates that younger captains had maintained their incomes, and those who are most dependent on lobsters had not. In addition, captains in controlling agreements (or license leases), or wider boats were more likely to report a decrease in their income since 2006, while those who owned groundfish quota or were making boat payments were less likely. Although wider boats can be used for participation in multiple fisheries and have a larger capacity for carrying lobster traps, boat width reduces vessel fuel efficiency. One captain reported that he had sold his boat and purchased a more efficient vessel to offset his fuel costs. The finding that captains with boat payments were less likely to report a decrease in their incomes contradicts the expectation that those with payments and debts would be most sensitive. This may be due to harvester misreporting, or to a low importance of boat payments relative to other factors and the lack of resolution of this binary variable. This interpretation is corroborated by further information on debt in Nova Scotia (see Barnett 2014 for details). Though the cost of licenses increased significantly after 1999, harvesters during this period more often reported obtaining loans from the Nova Scotia Loan Board than from banks. Harvesters further reported that this provincial loan agency was more lenient than private creditors. This suggests a need for more detailed analysis of fishing debt to understand its impacts on household livelihoods.

The results of a linear regression explaining crew-shares indicate similar patterns to previous models and expectations with some exceptions (Table 4). Dependence on lobster did not significantly explain the variance in crew shares in this case. Captains who entered the fishery with credit after 1999 or entered through controlling agreements had lower crew shares. Captains with longer boats or higher total catches also gave lower crew shares, though it is unclear whether higher catches would offset lower crew shares to maintain similar incomes for crew members. Boat length covaried positively with total catches $\left(\mathrm{R}^{2}=0.2850, \mathrm{P}<\right.$ 0.01). Finally, crew shares varied depending on whether shares were applied after or before expenses were subtracted from revenue for a fishing trip. This reflects different remuneration strategies captains use to incentivize crew members to keep fishing costs, e.g., bait and gear use, low. Crew shares were higher if they were calculated after expenses were deducted.

\section{Subjective well-being among harvesters and quota owners}

Overall, harvesters were not optimistic about the future of the lobster fishery and quota fisheries. Fifty-nine percent of harvesters responded that their access to the lobster fishery will be less in the future, $67 \%$ said their access to quota fisheries would be less, and only $2.7 \%$ said more. On average, captains who said their access to the quota fisheries would decline owned 20,864 pounds of quota while those who said their access would remain the same owned 3650 pounds (T-test assuming unequal variance, $\mathrm{P}<0.05)$. Those who owned more quota often pointed to the fact that overall groundfish quota allocations have declined significantly since the implementation of quota management, and they were not optimistic that the DFO would increase quotas in the future. Those who owned less did not see a future in which their access would return.

Further analysis on sense of well-being in the fishery compares whether a harvester would go into fishing if they had their life to live over again to whether they would advise their children to go into fishing either from scratch (having to buy or lease licenses and quota), with a lobster license, or with a lobster license and quotas (see Fig. 3). Although $90 \%$ of captains said that they would go into fishing again, only $7 \%$ said that they would probably or definitely advise their child to enter the fishery from scratch (Wilcoxon signed-rank test, $\mathrm{P}<0.0001$ ). Captains were more likely to advise their child to go into fishing if they could enter with a lobster license, and most likely if their child could enter with a lobster license and quotas. However, captains that would 
Table 2. Ordered logistic regression of factors explaining fishing household income.

\begin{tabular}{|c|c|c|c|c|}
\hline \multirow[t]{2}{*}{ Household income } & \multicolumn{2}{|c|}{ Full model } & \multicolumn{2}{|c|}{ Reduced model } \\
\hline & Odds ratio & SE & Odds Ratio & SE \\
\hline Age & $0.9189^{* *}$ & 0.0274 & $0.9107 * *$ & 0.0211 \\
\hline Boat payments & 1.0704 & 0.5298 & & \\
\hline Controlling agreements & 1.2492 & 0.4401 & & \\
\hline Credit after 1999 & 0.8324 & 0.6251 & & \\
\hline Groundfish quota & 1.0000 & 0.0000 & & \\
\hline Halibut (Hippoglossus hippoglossus) quota & 1.0000 & 0.0000 & & \\
\hline Swordfish (Xiphias gladius) quota & 1.0000 & 0.0001 & & \\
\hline Total catch & $1.0601 * *$ & 0.0234 & $1.0398 * *$ & 0.0128 \\
\hline$\%$ income from lobster (Homarus americanus) & $0.0138 * *$ & 0.0165 & $0.0189 * *$ & 0.0197 \\
\hline Boat length & 1.1436 & 0.0699 & $1.0919^{*}$ & 0.0476 \\
\hline Boat width & 0.8597 & 0.1050 & & \\
\hline $\mathrm{N}$ & 75 & & 81 & \\
\hline Likelihood Ratio $\chi^{2}$ & 69.73 & & 62.52 & \\
\hline P-value & $<0.0001$ & & $<0.0001$ & \\
\hline Pseudo $\mathrm{R}^{2}$ & 0.2551 & & 0.2303 & \\
\hline
\end{tabular}

themselves go into fishing if they had their lives to live over were still more likely to respond that they would "probably not" or "definitely not" advise their child to enter the fishery even if their child could enter with a lobster license (Wilcoxon signed-rank test, $\mathrm{P}<0.0001$ ), or with a lobster license and quotas (Wilcoxon signed-rank test, $\mathrm{P}=0.0409$ ).

Fig. 3. Survey responses to questions asking captains whether they would go into fishing again, and whether they would advise their child to go into fishing if they had to enter from scratch, with a lobster license, and with a lobster license and quotas.

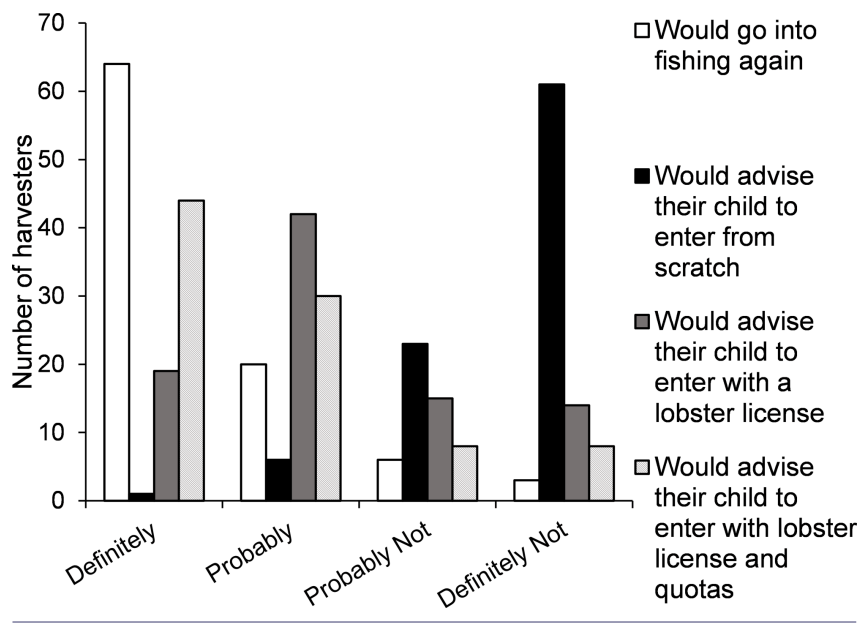

Figure 4 summarizes harvesters' responses regarding the best and the worst years they experienced in fishing from 1980 to 2012. Harvesters explained that the worst years were those when harvesters experienced low catches and prices (41\%), damage or loss of their fishing vessel $(15 \%)$, loss of access to the groundfishery $(15 \%)$, or poor weather $(9 \%)$. The best years were those when catches $(67 \%)$ and prices $(51 \%)$ were high, or when harvesters could fish for the full year $(26 \%)$, and thus had access
Fig. 4. Frequency histogram of years that harvesters reported as best and worst, with reference to significant events in southwest Nova Scotia fisheries (text boxes).

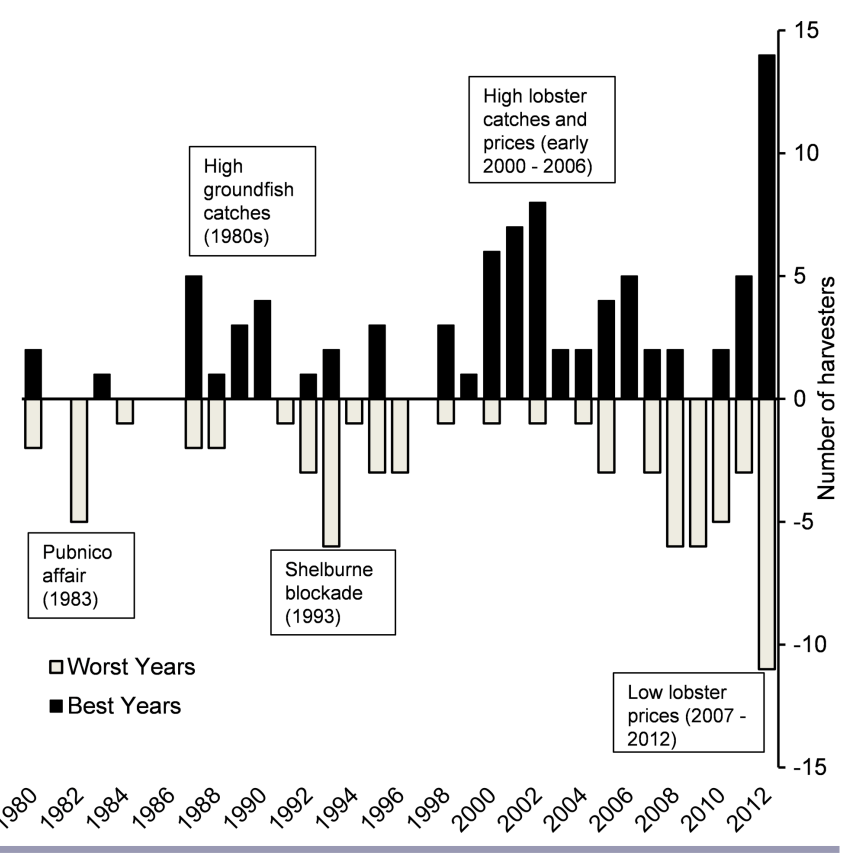

to multiple fish species. These responses correspond well with significant events in the history of the region including (1) the 1983 Pubnico affair, when enforcement officers intensified their efforts to enforce trap limits by seizing traps, and harvesters burned and sank two enforcement vessels (Davis and Kasdan 1984); (2) high groundfish catches in the late 1980s; (3) the 1993 Shelburne Blockade, when harvesters blockaded an industrial foreign trawler, protesting decreased allowable catches of groundfish, and continued allowances for foreign vessels to exploit Canadian fisheries; (4) the early 2000s when lobster catches and prices increased spurring increased investment and 
Table 3. Binomial logit model of factors explaining whether a captain's income has declined since 2006.

\begin{tabular}{|c|c|c|c|c|}
\hline \multirow[t]{2}{*}{ Income declined since 2006} & \multicolumn{2}{|c|}{ Full model } & \multicolumn{2}{|c|}{ Reduced model } \\
\hline & Odds ratio & SE & Odds Ratio & SE \\
\hline Age & $1.0812^{*}$ & 0.0382 & $1.0624 *$ & 0.0286 \\
\hline Boat payments & $0.1249^{* *}$ & 0.0977 & $0.1450^{* *}$ & 0.0997 \\
\hline Controlling agreements & $4.6907^{*}$ & 3.3471 & $3.2770^{*}$ & 1.7660 \\
\hline Credit after 1999 & 1.5232 & 1.7649 & & \\
\hline Groundfish quota & $0.9999^{*}$ & 0.0000 & $0.9999^{\dagger}$ & 0.0000 \\
\hline Halibut (Hippoglossus hippoglossus) quota & 1.0003 & 0.0002 & & \\
\hline Swordfish (Xiphias gladius) quota & 1.0003 & 0.0002 & & \\
\hline Total catch & 1.0229 & 0.0279 & & \\
\hline$\%$ income from lobster (Homarus americanus) & $152.82 * *$ & 235.76 & $70.458 * *$ & 91.783 \\
\hline Boat length & 0.9612 & 0.0942 & & \\
\hline Boat width & 1.2204 & 0.2216 & $1.3052^{*}$ & 0.1368 \\
\hline $\mathrm{N}$ & 83 & & 86 & \\
\hline Likelihood Ratio $\chi^{2}$ & 50.28 & & 41.48 & \\
\hline P-value & $<0.0001$ & & $<0.0001$ & \\
\hline Pseudo $\mathrm{R}^{2}$ & 0.4401 & & 0.3484 & \\
\hline
\end{tabular}

incomes in the lobster industry; (5) declining prices and increased costs for lobster fishing from 2007 to 2012 (Barnett 2014). Although most years in this 32-year history can be described as either best or worst, Figure 2 clearly shows that a split has emerged among harvesters, wherein nearly equal numbers of harvesters considered 2011 and 2012 as the best or worst year.

\section{DISCUSSION}

This study indicates further contributions could be made to enhance IFMPs according to the CFRN's sustainability framework. Although current IFMPs may align with some framework goals, Table 5 suggests indicators that could be used to further meet IFMP and CFRN Sustainability Framework goals. Based on the results above, I will discuss the relevance of goals and indicators under the dimensions of equity and fairness, economic and financial conditions, health and well-being, rules, and decision-making processes.

This study demonstrates that dependence on the lobster fishery is an essential indicator for holistic sustainability assessments in Barrington, and for lobster IFMPs. Household dependence on lobster as a source of income strongly influenced both household incomes, and income sensitivity. With greater dependence on lobster, harvesters have few alternatives if prices or catches decline (Barnett and Eakin 2015). Dependence on lobster in Barrington has increased substantially, and few harvesters have access to sufficient amounts of quota to maintain their fishing operations when the lobster fishing season is over. As in Maine, the lobster fishery is increasingly what Steneck et al. (2011) has referred to as a "gilded trap." Steneck et al. (2011), emphasized that this gilded trap has been caused by the economic success of lobster, and a simplified ecosystem due to overfishing. Atlantic Canadian ecosystems are similarly dominated by high lobster abundances, and harvesters have been pulled toward the economically attractive opportunities offered by the lobster fishery. But they have also been pushed toward the lobster fishery as opportunities decline in other fisheries. This study also further corroborates the claim that dependence on one high-value species increases the risks of economic and ecological disruptions. Today, household livelihoods in Barrington are dependent on the abundance, distribution, and price of lobster, and the results of this study suggest that this dependence puts them at greater risk.

Studies in Maine and the U.S. have similarly found increasing dependence on lobster, and a general trend toward decreasing diversity in access to fisheries (Donkersloot and Carothers 2017, Stoll et al. 2017). In Barrington, however, some relatively younger harvesters have maintained access to at least one, and as many as three additional fisheries. Older harvesters often reported a loss in access to fisheries, e.g., inshore groundfish using hand-lines, traditionally accessed through adjacency to fishing grounds, and since the introduction of limited-entry, through early access to affordable licenses. Younger harvesters have been able to enter quota fisheries, either through intergenerational transfers of quota, contracts with processors, or by buying or leasing quota. Thus, younger harvesters have been able to find ways to cope with a general decline in access to fisheries in the region. Overall, the implications of this strategy for livelihoods will depend on the cost of buying, leasing, or entering contracts to obtain quota.

While owning groundfish quota had a small and weakly significant influence on stabilizing income, the regressions also suggests that captains may be able to cope with low prices and low access to quota by simply intensifying their efforts and catching more lobsters. The finding that incomes decreased, and income sensitivity increased with age suggests that high effort fishing strategies may be more available to younger harvesters. The importance of catches and age suggests that despite the costs of entry, some younger captains have been able to keep ahead of costs by catching more. Catching more lobsters, however, often intensifies market gluts and further depresses prices (Holland 2011, Theriault et al. 2013), which makes it difficult for those who do not increase catches to maintain their fishing operations. Harvesters were trapped in the fishing equivalent of an agricultural treadmill (Cochrane 1958), whereby increasing effort and technological efficiency and inelastic demand for lobster results in decreasing prices, further incentivizing strategies to 
Table 4. Linear regression of factors explaining winter crew-shares.

\begin{tabular}{|c|c|c|c|c|}
\hline \multirow[t]{2}{*}{ Crew shares $(\%)$} & \multicolumn{2}{|c|}{ Full model } & \multicolumn{2}{|c|}{ Reduced model } \\
\hline & $\beta$ & SE (Robust) & $\beta$ & SE (Robust) \\
\hline Age & 0.0009 & 0.0008 & & \\
\hline Boat payments & -0.0070 & 0.0120 & & \\
\hline Controlling agreements & $-0.0190 \dagger$ & 0.0116 & $-0.0143 \dagger$ & 0.0086 \\
\hline Credit after 1999 & $-0.0240^{*}$ & 0.0181 & $-0.0342 *$ & 0.0144 \\
\hline Groundfish quota & 0.0000 & 0.0000 & & \\
\hline Halibut (Hippoglossus hippoglossus) quota & -0.0000 & 0.0000 & & \\
\hline Swordfish (Xiphias gladius) quota & -0.0000 & 0.0000 & & \\
\hline Total catch & $-0.0003^{*}$ & 0.0006 & $-0.0006^{*}$ & 0.0003 \\
\hline$\%$ income from lobster (Homarus americanus) & -0.0404 & 0.0363 & & \\
\hline Boat length & $-0.0033^{*}$ & 0.0023 & $-0.0041^{*}$ & 0.0019 \\
\hline Boat width & -0.0018 & 0.0026 & & \\
\hline Two or more crew & -0.0073 & 0.0169 & & \\
\hline Crew shares after expenses & $0.0557 * *$ & 0.0112 & $0.0540 * *$ & 0.0124 \\
\hline Constant & $0.3619 * *$ & 0.1015 & $0.3911 * *$ & 0.0875 \\
\hline $\mathrm{N}$ & 78 & & 83 & \\
\hline $\mathrm{F}$ & 9.19 & & 18.66 & \\
\hline P-value & $<0.0001$ & & $<0.048001$ & \\
\hline $\mathrm{R}^{2}$ & 0.5479 & & 0.52 & \\
\hline
\end{tabular}

increase production efficiency. This process may explain the divided outcomes (Fig. 4) among harvesters since the 2008 financial crisis. This suggests that indicators measuring how catches, effort, and well-being are distributed among harvesters in a single fishery, and across various fisheries can improve our understanding of fishing strategies and their implications for socioeconomic domains. Additionally, indicators of vessel capacity and its distribution among age-groups could be used to provide advice on the costs and benefits of various vessel configurations and associated fishing strategies.

Challenges to fishing households were not caused by a single regulatory event, but by the cumulative effects of multiple regulatory events, and a process of "creeping enclosure" (see Murray et al. 2010). Licensing and quota policies have changed the distribution of access to fish species, exacerbated inequalities in coastal communities, and made it more difficult for harvesters to maintain their incomes through flexibility when ecological or economic conditions change. Initial quota allocations, quota buyups, and the ecological decline of quota species such as groundfish have led to large inequalities in access to quota (McCay et al. 1995, Pinkerton and Edwards 2009, Barnett and Eakin 2015). Murray et al. (2010) suggest that the process of creeping enclosure can reduce the number of knowledgeable observers of ocean ecosystems, generate distrust, reduce social capital, and reduce the quantity and quality of information flow between managers and harvesters. Thus, holistic sustainability assessments require monitoring indicators that quantify how policies interact, and the implications for ecological, socioeconomic, and institutional aspects of Canada's fisheries.

Although studies have demonstrated that the benefits from initial quota allocations to harvesters often generate the dilemma of high costs for new entrants (Wiber 2000, Mansfield 2004, Bromley 2008, Pinkerton and Edwards 2009, Carothers and Chambers 2012, Brewer 2014, Pinkerton and Davis 2015), limited license fisheries are not immune to this dilemma. The transferability of licenses, though often intended to facilitate intergenerational transfers, has opened markets for lobster licenses, and controlling agreements have allowed some individuals and companies to lease out licenses. Harvesters who entered the fishery after licenses increased substantially in value did not report lower incomes or income sensitivity. However, those who entered the fishery through controlling agreements were less likely to maintain their incomes, and paid out lower crew shares. These results demonstrate that whether a fishing captain can maintain their livelihood in a fishery depends not only on the price and quantity of catch, or the costs of entering a fishery, but also the means available to enter the fishery. Further socioeconomic research may illuminate the dynamics of entry and major changes to access to fisheries that influence fishing livelihoods. By examining indicators of entry, such as controlling agreements, time of entry, costs of entry, and availability of credit, lobster IFMPs can develop mechanisms to promote intergenerational transfer of fishing access rights in coastal communities, and balance limitedentry requirements with the problems caused by high entry costs. Because of the risk of many complex unintended consequences, new policy should be collaborative, and accompanied with social and natural science research on the impacts on communities, households, captains, crewmembers, stocks, and ecosystems.

Harvesters in the 2012 survey were not optimistic about their future access to lobster and quota fisheries, whether they had access to quota and licenses or not. They also did not see a future for their children in the fisheries, especially if they had to enter the fishery without low cost or inherited lobster licenses and quotas. This sense of pessimism can discourage stewardship because harvesters are not confident that they will benefit from conservation measures (Ostrom 1990, Eakin and Wehbe 2009, van Putten et al. 2014). These findings further complicate the claim that owning property rights in natural resources enhances stewardship (Gilmour et al. 2012). Grainger and Costello (2014) 
Table 5. Proposed socioeconomic and institutional indicators from the Canadian Fisheries Research Network Sustainability Framework that could be used to enhance Maritimes lobster Integrated Fisheries Management Plans, based on this study's findings.

\begin{tabular}{|c|c|c|c|}
\hline Dimension & Goal & Indicators in southwest Nova Scotia & Benefit of indicator \\
\hline \multicolumn{4}{|l|}{ Socioeconomic domain } \\
\hline \multirow[t]{2}{*}{$\begin{array}{l}\text { Health and well- } \\
\text { being }\end{array}$} & Well-being & $\begin{array}{l}\text { Perception of future in fisheries for current and } \\
\text { future generations }\end{array}$ & $\begin{array}{l}\text { Improving contributions to conservation, sense of } \\
\text { stewardship }\end{array}$ \\
\hline & & Best and worst years in fishing & $\begin{array}{l}\text { Degree to which outcomes are shared among } \\
\text { harvesters, connections to historical events }\end{array}$ \\
\hline \multirow[t]{4}{*}{ Equity and fairness } & Fairness & Gini index of quota ownership & $\begin{array}{l}\text { Avoiding large inequities in access to quota } \\
\text { fisheries }\end{array}$ \\
\hline & Access stability & $\begin{array}{l}\text { Distribution of catch among harvesters in a } \\
\text { single fishery and across various fisheries }\end{array}$ & $\begin{array}{l}\text { Understanding different fisheries strategies and } \\
\text { potential implications }\end{array}$ \\
\hline & & $\begin{array}{l}\text { Quantification of major changes to access to } \\
\text { fisheries over time }\end{array}$ & $\begin{array}{l}\text { Understanding fishing revenues and landings } \\
\text { required for new entrants to meet entry costs }\end{array}$ \\
\hline & Costs and benefits & $\begin{array}{l}\text { Distribution of capacity and associated costs of } \\
\text { fishing }\end{array}$ & $\begin{array}{l}\text { Providing advice on vessel capacity to reduce } \\
\text { sensitivity to variables costs }\end{array}$ \\
\hline \multirow[t]{4}{*}{$\begin{array}{l}\text { Economic and } \\
\text { financial }\end{array}$} & Financial viability & Availability of capital/debt financing & $\begin{array}{l}\text { Developing affordable and appropriate means of } \\
\text { fishing access for new entrants }\end{array}$ \\
\hline & & $\begin{array}{l}\text { Quantification of enterprises dependent on one } \\
\text { fishery }\end{array}$ & $\begin{array}{l}\text { Understanding flexibility options available to } \\
\text { harvesters }\end{array}$ \\
\hline & & Income sensitivity & $\begin{array}{l}\text { Understanding what makes fishing households } \\
\text { sensitive to economic and ecological change }\end{array}$ \\
\hline & Labor & $\begin{array}{l}\text { Distribution of compensation among captains, } \\
\text { crew, processors, and financiers } \\
\text { Proportion of fishing captains subject to } \\
\text { controlling agreements or leasing agreements }\end{array}$ & $\begin{array}{l}\text { Improving economic conditions of owner- } \\
\text { operators and ensuring equitable distribution of } \\
\text { benefits along the value chain }\end{array}$ \\
\hline \multicolumn{4}{|l|}{ Institutional domain } \\
\hline Structure & Rules & Cumulative effects of multiple regulatory events & $\begin{array}{l}\text { Avoiding detrimental unintended consequences } \\
\text { that build over time reducing flexibility, social } \\
\text { capital, and trust }\end{array}$ \\
\hline \multirow[t]{2}{*}{$\begin{array}{l}\text { Decision-making } \\
\text { process }\end{array}$} & Collaborative & $\begin{array}{l}\text { Degree to which collaborative criteria exist and } \\
\text { are implemented }\end{array}$ & $\begin{array}{l}\text { Collaborating to build understanding and to } \\
\text { navigate trade-offs within and between } \\
\text { socioeconomic and ecological domains }\end{array}$ \\
\hline & Inclusive & $\begin{array}{l}\text { Degree to which inclusivity criteria exist and are } \\
\text { implemented }\end{array}$ & $\begin{array}{l}\text { Including coastal community and fishing groups } \\
\text { in decisions to ensure rules are appropriate to } \\
\text { social and ecological conditions }\end{array}$ \\
\hline
\end{tabular}

showed that fishing quotas do not confer security of tenure when there are ownership disputes, illegal fishing activities, or when owners believe that government will eventually revoke their fishing rights. These studies suggest a distinction between property rights to fish, and a more general sense of security among harvesters that access to fisheries will remain in coastal communities and fishing households. Barnett et al. (2017) show that there has been a consistent disregard for the effects of privatization of access rights on livelihood outcomes, and for the potential for collective action to improve decisions regarding property and access.

Though the Canadian licensing system may have too much momentum for drastic changes, improvements can be made by consulting with or granting some decision-making power over license and ITQ transfers to fishing communities. These measures had been used to manage entry prior to the current limited-entry licensing system (Levelton 1981, Matthews 1988, Gough 2007). Two recent developments suggest that legislative and legal conditions may be suitable for such innovations in licensing. First, the Supreme Court Elson decision has reaffirmed the Minister of Fisheries' absolute discretion in licensing, in consideration of not only stock and ecological conservation, but also social, cultural, or economic goals (Elson v. Canada 2017). Second, the Minister of Fisheries has pledged to enshrine owner-operator and fleetseparation policies into law, which are intended to keep licenses in the hands of small-scale independent harvesters (CBC News 2017). These developments open the possibility that harvesters, and coastal communities could play a greater role in decisions regarding access to fisheries. Criteria for collaborative decision making, such as powers sharing, and multiparty agreements and management plans would facilitate a negotiated process to navigate potential trade-offs within and between socioeconomic and ecological domains. Criteria for how various stakeholders and coastal community members could be included in decisions would facilitate rules that are appropriate to localized social and ecological conditions.

\section{CONCLUSION}

Owner-operator trends in Barrington, SWNS, have changed substantially since the DFO established management jurisdiction over its fishing grounds. Major changes in species abundances, caused by environmental change and overfishing, have spurred various allocation mechanisms and access-rights arrangements, and have changed the distribution of access to fisheries. Multispecies fishing has become a strategy available to fewer harvesters, and dependence on lobster has become prevalent. Limited-entry licensing, quotas, and third-party leasing 
agreements have changed the distribution of costs and benefits among captains. New strategies have emerged, and high-yield lobster fishing is often the best available strategy to pay bills and meet costs when lobster prices are low. Given a history of changing regulations and reduced options to remain flexible when economic and ecological conditions change, harvesters are pessimistic about their future access, and their children's future access, to fisheries.

The CFRN Sustainability Framework implies that managers should consider a larger set of objectives than the social, economic, and ecological objectives at present. The above results indicate that important socioeconomic and institutional indicators can enhance IFMPs to trigger assessment of, and mitigation measures for developing vulnerabilities, which might otherwise go unreported. These key aspects, and others beyond the scope of this paper, are currently not being tracked. This complicates our efforts to understand the holistic sustainability implications of policy change. The CFRN Sustainability Framework can guide researchers, managers, and fishing organizations to understand the current management objectives that are not being met, and to develop research priorities, methods, protocols, and personnel to meet a broader spectrum of objectives. Many CFRN collaborators envisioned a future at Fisheries and Oceans Canada that would incorporate a greater diversity of research streams and expertise, including anthropologists, geographers, sociologists, historians, citizen scientists, and local experts, to complement the current focus on biology, ecology, and economics. This model would move away from one of managing people through science, toward understanding human-environment interactions through diverse knowledges and dialogues.

Responses to this article can be read online at: http://www.ecologyandsociety.org/issues/responses. php/9981

\section{Acknowledgments:}

This research was funded by NSF (SES-0645789, BCS-026363), CNH (GEO-1115054), and by a Social Sciences and Humanities Research Council award (435-2014- 0299). This research was supported by a Social Sciences and Humanities Research Council Research Grant (\#410-83-0978), and by the Canadian Fisheries Research Network, funded by the Natural Sciences and Engineering Research Council of Canada (NETGP 389436-09).

\section{LITERATURE CITED}

Acheson, J. M. 1988. The lobster gangs of Maine. University Press of New England, Lebanon, New Hampshire, UK.

Adger, W. N. 2003. Social capital, collective action, and adaptation to climate change. Economic Geography 79 (4):387-404. http://dx.doi.org/10.1111/j.1944-8287.2003.tb00220. $\underline{\mathrm{X}}$

Armitage, D. R., R. Plummer, F. Berkes, R. I. Arthur, A. T. Charles, I. J. Davidson-Hunt, A. P. Diduck, N. C. Doubleday, D. S. Johnson, M. Marschke, P. McConney, E. W. Pinkerton, and E.
K. Wollenberg. 2009. Adaptive co-management for socialecological complexity. Frontiers in Ecology and the Environment 7(2):95-102. http://dx.doi.org/10.1890/070089

Barnett, A. J. D. 2014. From policy instruments to action arenas: toward robust fisheries and adaptive fishing households in southwest Nova Scotia. Dissertation. Arizona State University, Tempe, Arizona, USA.

Barnett, A. J., and J. M. Anderies. 2014. Weak feedbacks, governance mismatches, and the robustness of social-ecological systems: an analysis of the southwest Nova Scotia lobster fishery with comparison to Maine. Ecology and Society 19(4):39. http:// dx.doi.org/10.5751/ES-06714-190439

Barnett, A. J., and H. C. Eakin. 2015. "We and us, not I and me": justice, social capital, and household vulnerability in a Nova Scotia fishery. Applied Geography 59:107-116. http://dx.doi. org/10.1016/j.apgeog.2014.11.005

Barnett, A. J., R. A. Messenger, and M. G. Wiber. 2017. Enacting and contesting neoliberalism in fisheries: the tragedy of commodifying lobster access rights in Southwest Nova Scotia. Marine Policy 80:60-68. http://dx.doi.org/10.1016/j.marpol.2016.03.002

Bodiguel, C. 2002. Fishermen facing the commercial lobster fishery licensing policy in the Canadian Maritime Provinces: origins of illegal strategies, 1960-2000. Marine Policy 26 (4):271-281. http://dx.doi.org/10.1016/S0308-597X(02)00009-X

Breen, B., H. Kelley, and S. Hynes. 2016. The impact of precautionary quota constraints on the composition of multispecies harvest portfolios. Marine Policy 69:13-23. http://dx. doi.org/10.1016/j.marpol.2015.10.006

Brewer, J. F. 2012. Revisiting Maine's lobster commons: rescaling political subjects. International Journal of the Commons 6 (2):319-343. http://dx.doi.org/10.18352/ijc.336

Brewer, J. F. 2014. Hog daddy and the walls of steel: catch shares and ecosystem change in the New England groundfishery. Society and Natural Resources 27(7):724-741. http://dx.doi. org/10.1080/08941920.2014.905811

Bromley, D. W. 2008. The crisis in ocean governance: conceptual confusion, spurious economics, political indifference. MAST: Maritime Studies 6(2):7-22.

Bromley, D. W. 2009. Abdicating responsibility: the deceits of fisheries policy. Fisheries 34(6):280-290. http://dx.doi. org/10.1577/1548-8446-34.6.280

Canadian Fisheries Research Network (CFRN). 2012. Canadian Fisheries Research Network. CFRN, Fredericton, New Brunswick, Canada. [online] URL: http://www.cfrn-rcrp.ca/ Public-Home-EN

Carothers, C., and C. Chambers. 2012. Fisheries privatization and the remaking of fishery systems. Environment and Society: Advances in Research 3(1):39-59. http://dx.doi.org/10.3167/ ares.2012.030104

Cash, D. W., W. N. Adger, F. Berkes, P. Garden, L. Lebel, P. Olsson, L. Pritchard, and O. Young. 2006. Scale and cross-scale dynamics: governance and information in a multilevel world. Ecology and society 11(2):8. http://dx.doi.org/10.5751/ES-01759-110208 
CBC News. 2017. Dominic LeBlanc pledges to 'enshrine the owneroperator and fleet separation law.' 26 July. [online] URL: http:// www.cbc.ca/news/canada/nova-scotia/leblanc-fisheries-owner-operatorfleet-separation-law-1.4221716.

Chaffin, B. C., and L. H. Gunderson. 2016. Emergence, institutionalization and renewal: rhythms of adaptive governance in complex social-ecological systems. Journal of Environmental Management 165:81-87. http://dx.doi.org/10.1016/j.jenvman.2015.09.003

Coates, K. 2000. The Marshall Decision and native rights. McGill Queen's University Press, Montréal, Québec, Canada.

Cochrane, W. W. 1958. Farm prices: myth and reality. University of Minnesota Press, Minneapolis, Minnesota, USA.

Daigle, C. P., D. K. Loomis, and R. B. Ditton. 1996. Procedural justice in fishery resource allocations. Fisheries 21(11):18-23. http://dx.doi.org/10.1577/1548-8446(1996)021<0018:PJIFRA>2.0. $\mathrm{CO} ; 2$

Davis, A. 1980. "You're your own boss": an economic anthropology of small boat fishing in Port Lameron Harbour, southwest Nova Scotia. Dissertation. University of Toronto, Toronto, Ontario, Canada.

Davis, A. 1984. Property rights and access management in the small boat fishery: A case study from Southwest Nova Scotia. Dalhousie Ocean Studies Programme, Halifax, Nova Scotia, Canada.

Davis, A. 1991. Insidious rationalities: the institutionalisation of small boat fishing and the rise of the rapacious fisher. Maritime Anthropological Studies 4(1):13-31.

Davis, A., and L. Kasdan. 1984. Bankrupt government policies and belligerent fishermen responses: dependency and conflict in the southwest Nova Scotia small boat fisheries. Journal of Canadian Studies 19(1):108-124. http://dx.doi.org/10.3138/ jes.19.1.108

Degnbol, P., H. Gislason, S. Hanna, S. Jentoft, J. Raakjær Nielsen, S. Sverdrup-Jensen, and D. Clyde Wilson. 2006. Painting the floor with a hammer: technical fixes in fisheries management. Marine Policy 30(5):534-543. http://dx.doi.org/10.1016/j.marpol.2005.07.002

Department of Fisheries and Oceans Canada (DFO). $2016 a$. Lobster (Homarus americanus) off Southwest Nova Scotia (Lobster Fishing Area 34): 2015 Stock status update. Stock Status Update, Canadian Science Advisory Secretariat Science Response 2016/037. DFO, Ottawa, Ontario, Canada.

Department of Fisheries and Oceans Canada (DFO). $2016 b$. Lobster (Homarus americanus) off the Atlantic Coast of Nova Scotia (Lobster Fishing areas 27-33). Stock Status Update, Canadian Science Advisory Secretariat Science Response 2016/025. DFO, Ottawa, Ontario, Canada.

Department of Fisheries and Oceans Canada (DFO). 2017. Stock status update of Atlantic Halibut on the Scotian Shelf and Southern Grand Banks (NAFO Divs. 3NOPs $4 W W X Z \mathrm{Zc}$ ). DFO Canadian Science Advisory Science Response 2017/021. DFO, Ottawa, Ontario, Canada.

Donkersloot, R., and C. Carothers. 2017. Beyond privatization: rethinking fisheries stewardship and conservation in the North Pacific. Pages 253-270 in P. S. Levin and M. R. Poe, editors.
Conservation for the Anthropocene ocean. Academic Press, Cambridge, Massachusetts, USA. http://dx.doi.org/10.1016/ B978-0-12-805375-1.00012-X

Eakin, H., and L. A. Bojórquez-Tapia. 2008. Insights into the composition of household vulnerability from multicriteria decision analysis. Global Environmental Change 18(1):112-127. http://dx.doi.org/10.1016/j.gloenvcha.2007.09.001

Eakin, H. C., and M. B. Wehbe. 2009. Linking local vulnerability to system sustainability in a resilience framework: two cases from Latin America. Climatic Change 93(3-4):355-377. http://dx.doi. org/10.1007/s10584-008-9514-X

Elson v. Canada. 2017. FC 459 (CanLII). http://canlii.ca/t/h3p49

Eriksen, S., and J. Lind. 2009. Adaptation as a political process: adjusting to drought and conflict in Kenya's drylands. Environmental Management 43(5):817-835. http://dx.doi.org/10.1007/ s00267-008-9189-0

Foley, P., C. Mather, and B. Neis. 2015. Governing enclosure for coastal communities: social embeddedness in a Canadian shrimp fishery. Marine Policy 61:390-400. http://dx.doi.org/10.1016/j. marpol.2014.11.009

Frank, K. T., B. Petrie, J. A. D. Fisher, and W. C. Leggett. 2013. Setting the record straight on drivers of changing ecosystem states. Fisheries Oceanography 22(2):143-146. http://dx.doi. org/10.1111/fog. 12007

Gilmour, P. W., R. W. Day, and P. D. Dwyer. 2012. Using private rights to manage natural resources: is stewardship linked to ownership? Ecology and Society 17(3):1. http://dx.doi. org/10.5751/ES-04770-170301

Gough, J. 2007. Managing Canada's fisheries: from early days to the year 2000. Septentrion, Sillery, Québec, Canada.

Grainger, C. A., and C. J. Costello. 2014. Capitalizing property rights insecurity in natural resource assets. Journal of Environmental Economics and Management 67(2):224-240. http:// dx.doi.org/10.1016/j.jeem.2013.12.005

Grootaert, C. B., and T. Van Bastelar. 2002. Understanding and measuring social capital: a multidisciplinary tool for practitioners. The World Bank, Washington, D.C., USA. http://dx.doi. org/10.1596/0-8213-5068-4

Hanna, S. S. 1998. Institutions for marine ecosystems: economic incentives and fishery management. Ecological Applications 8 (sp1):S170-S174. http://dx.doi.org/10.1890/1051-0761(1998)8[S170: IFMEEI]2.0.CO:2

Harlan, S. 2003. The Phoenix area social survey: community and environment in a desert metropolis: summary results of the pilot study. Center for Environmental Studies, Arizona State University, Tempe, Arizona, USA.

Hilborn, R., J.-J. Maguire, A. M. Parma, and A. A. Rosenberg. 2001. The precautionary approach and risk management: can they increase the probability of successes in fishery management? Canadian Journal of Fisheries and Aquatic Sciences 58(1):99-107. http://dx.doi.org/10.1139/f00-225

Holland, D. S. 2011. Optimal intra-annual exploitation of the Maine lobster fishery. Land Economics 87(4):699-711. http://dx. doi.org/10.3368/le.87.4.699 
Levelton, C. R. 1981. Toward an Atlantic coast commercial fisheries licensing system: a report prepared for the Department of Fisheries and Oceans, Government of Canada. Communications Branch, Department of Fisheries and Oceans, Ottawa, Ontario, Canada.

Loomis, D. K., and R. B. Ditton. 1993. Distributive justice in fisheries management. Fisheries 18(2):14-18. http://dx.doi. org/10.1577/1548-8446(1993)018<0014:DJIFM>2.0.CO;2

Macinko, S. 2014. Lipstick and catch shares in the Western Pacific: beyond evangelism in fisheries policy? Marine Policy 44:37-41. http://dx.doi.org/10.1016/j.marpol.2013.08.004

Mansfield, B. 2004. Neoliberalism in the oceans: "rationalization," property rights, and the commons question. Geoforum 35 (3):313-326. http://dx.doi.org/10.1016/j.geoforum.2003.05.002

Marshall, N. A. 2011. Assessing resource dependency on the rangelands as a measure of climate sensitivity. Society \& Natural Resources 24:1105-1115. http://dx.doi.org/10.1080/08941920.2010.509856

Marshall, N. A., D. M. Fenton, P. A. Marshall, and S. G. Sutton. 2007. How resource dependency can influence social resilience within a primary resource industry. Rural Sociology 72 (3):359-390.

Matthews, R. 1988. Federal licensing policies for the Atlantic inshore fishery and their implementation in Newfoundland, 1973-1981. Acadiensis 17(2):83-108.

McCay, B. J., C. F. Creed, A. C. Finlayson, R. Apostle, and K. Mikalsen. 1995. Individual transferable quotas (ITQs) in Canadian and US fisheries. Ocean and Coastal Management 28 (1-3):85-115. http://dx.doi.org/10.1016/0964-5691(95)00068-2

McCay, B. J., and S. Jentoft. 1998. Market or community failure? Critical perspectives on common property research. Human Organization 57(1):21-29. http://dx.doi.org/10.17730/

humo.57.1.372712415k227u25

Murray, G., T. Johnson, B. J. McCay, M. Danko, K. St Martin, and S. Takahashi. 2010. Cumulative effects, creeping enclosure, and the marine commons of New Jersey. International Journal of the Commons 4(1):367-389. http://dx.doi.org/10.18352/ijc.148

Ostrom, E. 1990. Governing the commons: the evolution of institutions for collective action. Cambridge University Press, New York, New York, USA. http://dx.doi.org/10.1017/CBO9780511807763

Parlee, C. E., and M. G. Wiber. 2014. Institutional innovation in fisheries governance: adaptive co-management in situations of legal pluralism. Current Opinion in Environmental Sustainability 11:48-54. http://dx.doi.org/10.1016/j.cosust.2014.09.012

Pinkerton, E. 2009. Coastal marine systems: conserving fish and sustaining community livelihoods with co-management. Pages 241-257 in C. Folke, G. P. Kofinas, and F. S. Chapin, editors. Principles of ecosystem stewardship. Springer, New York, New York, USA. http://dx.doi.org/10.1007/978-0-387-73033-2_11

Pinkerton, E., and R. Davis. 2015. Neoliberalism and the politics of enclosure in North American small-scale fisheries. Marine Policy 61:303-312. http://dx.doi.org/10.1016/j.marpol.2015.03.025

Pinkerton, E., and D. N. Edwards. 2009. The elephant in the room: the hidden costs of leasing individual transferable fishing quotas.
Marine Policy 33(4):707-713. http://dx.doi.org/10.1016/j. marpol.2009.02.004

Plummer, R. 2009. The adaptive co-management process: an initial synthesis of representative models and influential variables. Ecology and Society 14(2):24. http://dx.doi.org/10.5751/ ES-03130-140224

Ruitenbeek, J., and C. Cartier. 2001. The invisible wand: adaptive co-management as an emergent strategy in complex bio-economic system. Center for International Forestry Research, Bogor, Indonesia.

Sayles, J. S., and J. A. Baggio. 2017. Social-ecological network analysis of scale mismatches in estuary watershed restoration. Proceedings of the National Academy of Sciences 114(10):E1776E1785. http://dx.doi.org/10.1073/pnas.1604405114

Sinclair, M., M. Power, E. Head, W. K. W. Li, M. McMahon, R. Mohn, R. O'Boyle, D. Swain, and J. Tremblay. 2015. Eastern Scotian Shelf trophic dynamics: a review of the evidence for diverse hypotheses. Progress in Oceanography 138:305-321. http:// dx.doi.org/10.1016/j.pocean.2015.09.005

Steneck, R. S., T. P. Hughes, J. E. Cinner, W. N. Adger, S. N. Arnold, F. Berkes, S. A. Boudreau, K. Brown, C. Folke, L. Gunderson, P. Olsson, M. Scheffer, E. Stephenson, B. Walker, J. Wilson, and B. Worm. 2011. Creation of a gilded trap by the high economic value of the Maine lobster fishery. Conservation Biology 25(5):904-912. http://dx.doi.org/10.1111/j.1523-1739.2011.01717. $\underline{\mathrm{X}}$

Stephenson, R. L., A. J. Benson, K. Brooks, A. Charles, P. Degnbol, C. M. Dichmont, M. Kraan, S. Pascoe, S. D. Paul, A. Rindorf, and M. Wiber. 2017. Practical steps toward integrating economic, social and institutional elements in fisheries policy and management. ICES Journal of Marine Science 74(7):1981-1989. http://dx.doi.org/10.1093/icesjms/fsx057

Stoll, J. S., C. M. Beitl, and J. A. Wilson. 2016. How access to Maine's fisheries has changed over a quarter century: the cumulative effects of licensing on resilience. Global Environmental Change 37:79-91. http://dx.doi.org/10.1016/j.gloenvcha.2016.01.005

Stoll, J. S., E. Fuller, and B. I. Crona. 2017. Uneven adaptive capacity among fishers in a sea of change. PLoS ONE 12(6): e0178266. http://dx.doi.org/10.1371/journal.pone.0178266

Theriault, G., J. Hanlon, and L. Creed. 2013. Report of the maritime lobster panel. Report to Minister of Agriculture, Aquaculture and Fisheries (New Brunswick), Minister of Fisheries and Aquaculture (Nova Scotia), and Minister of Fisheries, Aquaculture and Rural Development (Prince Edward Island), Canada.

Trzcinski, M. K., and W. D. Bowen. 2016. The recovery of Atlantic halibut: a large, long-lived, and exploited marine predator. ICES Journal of Marine Science 73(4):1104-1114. http:// dx.doi.org/10.1093/icesjms/fsv266

van Putten, I., F. Boschetti, E. A. Fulton, A. D. M. Smith, and O. Thebaud. 2014. Individual transferable quota contribution to environmental stewardship: a theory in need of validation. Ecology and Society 19(2):35. http://dx.doi.org/10.5751/ ES-06466-190235 
Wiber, M. G. 2000. Fishing rights as an example of the economic rhetoric of privatization: calling for an implicated economics. Canadian Review of Sociology/Revue canadienne de sociologie 37 (3):267-288. http://dx.doi.org/10.1111/j.1755-618X.2000.tb00591. $\underline{\mathrm{X}}$

Wise, R. M., I. Fazey, M. Stafford Smith, S. E. Park, H. C. Eakin, E. R. M. Archer Van Garderen, and B. Campbell. 2014. Reconceptualising adaptation to climate change as part of pathways of change and response. Global Environmental Change 28:325-336. http://dx.doi.org/10.1016/j.gloenvcha.2013.12.002 